\title{
The quantity of neutrophil and macrophage after the application of red ginger on white rats with chronic periodontitis
}

\author{
Ridha Andayani*, Santi Chismirina*, Hessyi Amanda Pratiwi*, Melati Hayatul Husni* \\ *Department of Oral Biology Faculty of Dentistry Universitas Syiah Kuala, Banda Aceh, Aceh, \\ Indonesia
}

\begin{abstract}
Introduction: Chronic periodontitis is the most common form of periodontitis. The major etiology of periodontitis is Gram-negative anaerobic bacteria, such as Aggregatibacter actinomycetemcomitans, Treponema denticola, Tannarela forsythia and Porphyromonas gingivalis which locally invade periodontal tissues and affect the immune system cells. Neutrophils and macrophage play central role in inflammation. The objective of study was to evaluate the quantity of neutrophil and macrophage due to the application of red ginger (Zingiber officinale var rubrum) extract of rat chronic periodontitis. Methods: The type of this research is experimental laboratoris post test only control group. In order to induce experimental periodontitis, the mandibular insisivus was assigned to receive wire 0.008 inch in marginal gingival. Then, red ginger extract that has bioactive compounds was topically administered to the rats. Result: this study showed there were no neutrophils in histopathologic of rat's periodontal tissue, but there were amount of macrophage. Then macrophage analyzed by one way ANOVA showed significant differences in each group $(p<0.05)$ and continued with LSD. Conclusions: there was no effect of red ginger extract toward the quantity of neutrophils, but affected on the number of macrophage.
\end{abstract}

Keywords: inflammation, periodontal tissues, $P$. gingivalis, gingerol

\section{INTRODUCTION}

Periodontitis is an inflammation on periodontal tissues caused by specific microorganisms or groups of microorganisms that cause specific damage to the connective tissue and bone that support the teeth. ${ }^{1.2}$ Chronic periodontitis is the most common periodontitis which occurs in adults, but can also occurs in children ${ }^{1}$. The results of research by Albandar and Tinoco at the age of 11-25 years shows that the prevalence of chronic periodontitis in Western Europe, North America, South America, Africa and Asia each of 1-3, 2-5, 4-8, 10-20, and $5-8 \% .^{3}$

Chronic periodontitis associated with the induction of the bacteria Gram negative anaerobic, such as Aggregatibacter actinomycetemcomitans (27.6\%), Treponema denticola (33.6\%), Tannarela forsythia (41.4\%), Porphyromonas gingivalis (46.6\%), Porphyromonas gingivalis. ${ }^{4}$ (p. gingivalis) is a bacterial cause of occurrence of chronic periodontal disease. The bacterias causes this

Corresponding author: Ridha Andayani, Department of Oral Biology Faculty of Dentistry Universitas Syiah Kuala Jl. Teuku Nyak Arief Darussalam, Banda Aceh, Aceh, Indonesia, 23111. Email: ridha_andayani@yahoo.com 
periodontitis can trigger the emergence of immune responses and inflammatory cells. ${ }^{6}$

For examples, the immune cells that play a role in inflammatory processes are neutrophils and macrophages. ${ }^{7}$ Neutrophil is a non spesific inflammatory cell which first appeared in large numbers in the exudate on the first hour of the inflammation. There are approximately 5000 neutrophils per millimeter cubic of blood in circulation at any time. ${ }^{8.9}$ Neutrophils migrate into the blood circulation, infiltration into the tissue, and phagocytosis. ${ }^{10}$ Neutrophils are the characteristics of acute inflammation, but can also be found in chronic inflammation, such as a bacterial infection or tissue necrosis. ${ }^{11}$

The macrophage is a cell which also appears on the early inflammatory. Macrophages are able to do phagocytosis for a large number of bacteria, viruses, tissue necrotic, or other foreign molecules. ${ }^{12}$ On chronic inflammatory, the antigen which persistent antigen would cause the activation and accumulation of macrophages continuously. ${ }^{7}$

The using of antibiotics is one of the efforts for handling the inflammatory, healing the tissue, eliminate the bacteria that causes infection. Metronidazole is an antibiotic used to treat periodontal disease against anaerobic bacteria such as Porphyromonas sp. and Prevotella sp. but, metronidazole has some side effects such as stomachace, headache, nausea, and changes of flavor on the tongue. ${ }^{13,14}$ Therefore, herbal medicines are derived from plants, can be used because giving the effect for the body, safe for consumption, and the cost is cheap..$^{15}$ One of the plants that is useful for health is ginger. ${ }^{16}$

Red ginger (Zingiber officinale var. rubrum) has an analgesic effects and a bitter taste. The substances which being an analgesic and noninflammatory is gingerol and shogaol. ${ }^{17}$ The result of research conducted by Jolad et al. ${ }^{18}$ showed that gingerol inhibits the production of prostaglandin that induced by lipopolysaccharide (LPS) and according to Levy et al. ${ }^{19}$ found that 6-shogaol decreasing the inflammatory responses. The other studies by Shimoda et al. against $40 \%$ ethanol extract of red ginger stated that there is a suppression effect of acute and chronic inflammatory. ${ }^{17}$ The objective of this research is to recognize the quantity of neutrophils and macrophages in consequence of the application of red ginger extract in white rats (Rattus norvegicus) with chronic periodontitis.

\section{METHODS}

The type of this research is experimental laboratoris post test only control group. The procedure of research include the manipulation of chronic periodontitis in rats, production of red ginger extracts and test of phytochemicals, the giving of extracts in rats, and the creation of histopathology tissue of rats's periodontal tissue.

The manipulation of chronic periodontitis performed on white rats were divided into four groups; two groups of controls (positive and negative) and two groups of treatment (50 and $100 \%$ concentration of extracts). Rats were being intramuscular anastetic with the combination of ketamine hydrochloride and xylazine hydrochloride to be injected in the left leg at the musculus tricep. Wire with diameter 0.008 inches was mounted on servical area of the mandibular insisivus and fixed on the marginal using a needle holder for 11 days without moving parts.

The production of extracts is done by extracting the red ginger with ethanol. Red ginger that still fresh and reddish-colored (orange) were selected, then being washed cleanly and weighed for $3 \mathrm{~kg}$ and then sliced and dried under the sun but not directly for 7 days. Simplisia is milled to a powder as much as 500 grams. The result is being maserated for 7 days in ethanol and filtered. The filtrate is evaporated in a vacuum rotary evaporator $40^{\circ} \mathrm{C}$ until it becomes thick (extract). The extracts are then placed in sterile jars and covered with aluminum foil. The results of the extraction are regarded as $100 \%$ of the initial concentration. Then, the extract diluted to $50 \%$ of concentration gets by adding aquades. The phytochemicals test is done such as alkaloids, flavonoids, phenols, saponins and tannins test.

The application of extract is done after the making of periodontitis in rats. Red ginger extract is done twice a day for 6 days by using the syringe as much as $1.5 \mathrm{ml}$. Each group the treatment applied to extract the red ginger and the concentration of $50 \%$ and $100 \%$, while the negative control group was given by aquadest and a positive control group was given metronidazole. 
Table 1. The average number of macrofag cells on rat's periodontal tissue which having a periodontitis after doing the experiment

\begin{tabular}{ccccc}
\hline \multirow{2}{*}{ Sample } & \multicolumn{4}{c}{ The average number of macrophage cells with 5 views } \\
\cline { 2 - 5 } & Negative control (aquades) & Positive control (Metronidazole) & Red ginger 50\% & Red ginger 100\% \\
\hline Rats 1 & 3.20 & 2.80 & 2.80 & 2.80 \\
Rats 2 & 2.80 & 2.60 & 3.00 & 2.40 \\
Rats 3 & 3.40 & 2.40 & 3.20 & 2.60 \\
Average & 3.13 & 2.60 & 3.00 & 2.60 \\
\hline
\end{tabular}

Table 2. The results of test LSD

\begin{tabular}{ccccc}
\hline Experimental group & Negative control & Positive control & Red ginger 50\% & Red ginger $100 \%$ \\
\hline Negative control & - & $0.022^{*}$ & 0.500 & $0.22^{*}$ \\
Positive control & $0.022^{*}$ & - & 0.067 & 1.000 \\
Red ginger 50\% & 0.500 & 0.067 & - & 0.067 \\
Red ginger 100\% & $0.22^{*}$ & 1.000 & 0.067 & - \\
\hline
\end{tabular}

Note: ${ }^{*}$ value $p<0,05$, there is a different meaning

Animals try to be euthanasion using chloroform on the $18^{\text {th }}$ day. The specimen is then created by cutting the area of periodontal tissue to do the processing and making the tissue preparations and counting the cell number of neutrophils and macrophages.

\section{RESULT}

The results showed that the number of neutrophil cells are not found in all groups. Whereas, the highest number of macrophage cells are present in the group, that is the result of observations on the sample research retrieved data as listed in Table 1.

From the data above, it can be noted that the number of macrophages are present in most of the negative control group followed by $50 \%$ treatment group, while the lowest number of macrophages is present in positive control group and $100 \%$ treatment group. The data analysis was done with one way ANOVA. The test results indicate the presence of the influence of red ginger to the number of macrophages with $p=0.045(p<0.05)$.

Then, LSD test was done to see the differences between groups. The results stated that there is a difference between the negative control group with the positive control group and red ginger treatment group 100\%, but does not differ meaningfully with $50 \%$ red ginger treatment groups. There was no meaningful difference with
$50 \%$ of the treatment group against $100 \%$ red ginger treatment (Table 2).

\section{DISCUSSION}

The results showed no neutrophils were found. This is because the short lifetime of neutrophils. ${ }^{20}$ Some literatures stated that the lifetime of neutrophils around 5-6 a days, after that the neutrophils will do apoptosis or programmed death cell spontaneously. ${ }^{21}$ Refer to the results of study, the neutrophils were not found because the manipulation of chronic periodontitis during 11 days exceeds the lifetime of neutrophils. Meanwhile, many cells that mostly found are macrophages and lymphocytes because naturally the host response is mediated by lymphocytes and macrophages. ${ }^{22}$

Neutrophils are the characteristic of acute inflammatory, although neutrophils are also found in chronic inflammation, such as a bacterial infection. The evidence of neutrophils in chronic inflammatory found at the research of Najih Rama that examined the analysis of change in the number and type of PMN cells of a chronic sinusitis patients on treatment of grain white rice also found neutrophils with different amounts of some a groups. ${ }^{23}$ Another studies by Wijaya et al. who saw the percentage of neutrophils in people with chronic obstructive pulmonary disease (COPD/ COPD) found that there were number of neutrophils 
in their sputum. ${ }^{24}$ This is supposedly because the lungs as an organ of respiration could be entered by microorganisms from the outside through the respiratory tract, so that in that chronic condition can allow the acute inflammatory that proven by the discovery of neutrophils.

Neutrophils which found in chronic inflammatory bind the IL-17 to produce CD4+ lymphocytes T. Neutrophils itself has a very important role in the production of IL-17, but when neutrophils undergo apoptosis, neutrophils triggered the non-inflammatory response by a reduction in the production of IL-23. IL-23 itself is the main cytokines that induce the production of IL-17 and from different cells in the immune system. ${ }^{25}$ When CD4+T-helper lymphocytes interacted with antigen presenting cells, $T$ cells will differentiate into several cell types such as Th1, Th2, Th17, depending on the cytokines that are produced. Th1 cell will mediate the cell immune response by producing cytokines, while Th17 will act as autoimmunity and maintain the immune homeostasis maintain. ${ }^{22}$

When the onset of apoptosis, neutrofil will send a signal in order to be detected by macrophage, macrophages will phagosit the died neutrophils. The process of macrophage phagosited the dead neutrophils is called efferocytosis. This process is described as the completion of inflammatory process and the initiation tissue repair, but the process of efferocytosis can also be due to disease have persistent or may have become chronic. Therefore, the lifetime of neutrophils and mechanisms that control its death may be caused by the effectivity of disease therapy and could be caused by disease that become chronic inflammatory. ${ }^{26}$ To achieve it, understanding the underlying mechanism activities, migration, and the defense of life and the onset of neutrophil apoptosis will give us the right approach and more relevant to treat chronic inflammatory conditions. ${ }^{27}$

Application of red ginger extract can decrease the number of macrophages. When the smallest number of macrophages that in this research group is present on the concentration of $100 \%$ red ginger. It is suspected that at red ginger with a concentration $100 \%$ containing more active substances, so that the ability of red ginger decreases the inflammation higher than $50 \%$ red ginger. This is similar to the research of Aldelina et al. concerning the number of macrophages on periodontitis of white rats after application of young papaya leaf extract demonstrated that there were a differences in the number of macrophages in each group where a group of young papaya leaf extract concentration was the highest, which was $75 \%$ have the smallest number of macrophages than th other treatment groups. Young papaya leaf also has the effect of non-inflammatory because it contains active ingredients such as flavonoids that also owned by red ginger. ${ }^{28}$

Red ginger contains gingerol and shogaol. Gingerol and shogaol have non-inflammatory potential to inhibit the inflammatory mediators such as prostaglandins, Tumor Necrosis Factor (TNF)-a, interleukin (IL)-6, and IL-8. ${ }^{29}$ Red ginger also contains flavonoids (anthocyanins and proanthocyanidins) that can inhibit the activities of pro-inflamatory cytokines such as TNF $a$ and IL6. ${ }^{30,31}$

The pro-inflammatory cytokine production can cause more severe damage on alveolar bone destruction include periodontitis by the activation of osteoclasts. ${ }^{32}$ Osteoclasts formed due to inflammatory cells such as secretion of cytokines. ${ }^{33}$ Some examples of the cytokines are prostaglandins, IL-1, IL-a 1 B, IL-6, IL-12, IL18, TNF $\alpha$ and TNF B. ${ }^{7,34}$ Cytokines can also play a role in stimulating the recruitment of inflammatory cells, such as IL-1 can increase the production of neutrophils and monocytes, the release of inflammatory mediators also can improve the adhesion molecules both on inflammatory cells and in endothelial cells. It improves the adhesion, marginatation and migration of neutrophil cells, monocytes and eosinophils to the center of inflammation. ${ }^{7}$ This led to a decrease number of macrophage inflammatory mediators, as that can increase production and improve adhesion of leukocytes to endothelial cells is inhibited by the activities of non-inflammatory effect of Red ginger, so the number of macrophages will decrease.

The ability of red ginger is decreasing the number of macrophages which same as the positive control group (metronidazole). This is suspected because beside having the activity of noninflammatory, red ginger also have antibacterial effects same as metronidazole which is antibiotic drugs, so ginger red and metronidazole may inhibit 
the growth of bacteria. The antibacterial effects of red ginger can inhibit the bacteria so that the amount of bacterial colonization decreased an the virulence ability also decreased and the number of cells of the macrophage also decreased. ${ }^{28}$

\section{CONCLUSION}

There were no neutrophils on each group's treatment, but there was a difference in the number of macrophages in each treatment groups. It is expected to do further research about the process of healing the periodontitis after application of red ginger extract (z. officinale var. rubrum).

\section{REFERENCES}

1. Hinrichs JE, Novak MJ. Classification of diseases and conditions affecting the periodontium. In: Newman MG, Takei HH, Carranza FA. Carranza's clinical periodontology. $11^{\text {th }}$ ed. Philadelphia: WB Saunders; 2012. p. 41-2.

2. Agnihotram G, Singh TRM, Pamidimarri G, Jacob L, Rani S, Sravanthi. Study of clinical parameters in chronic periodontitis. Int J Appl Biol Pharmaceut Technol 2010;1(3):1202-8.

3. Albandar JM, Tinoco EMB. Global epidemiology of periodontal diseases in children and young persons. Periodontology 2002;29:153-76.

4. Farias BC, Souza PRE, Ferreira B, Melo RSA, Machado FB, Gusmao ES, et al. Occurrence of periodontal pathogens among patients with chronic periodontitis. Braz J Microbiol 2012: 909-16.

5. Chaudhary V, Kishore $B$, Rao S, Ingalagi $P$, Kugaji M. Comparison of culture and PCR for detection of Porphyromonas gingivalis in patients with chronic periodontitis and healthy subjects. J Pharmaceut Biomed Scie 2013;34(34):1670-5.

6. Dalimunthe SH. Periodonsia. Medan: Departemen Periodonsia Fakultas Kedokteran Gigi Universitas Sumatera Utara; 2008. p. 82.

7. Baratawidjaja KG, Rengganis I. Imunologi dasar. $8^{\text {th }}$ ed. Jakarta: Balai Penerbit FKUI; 2009. p. 273, 279.

8. Sherwood L. Fisiologi manusia: dari sel ke sistem. $2^{\text {rd }}$ ed. Jakarta: EGC; 2001. p. 367, 369.
9. Price SA, Wilson LM. Patofisiologi: konsep klinis proses-proses penyakit. $6^{\text {th }}$ ed. Jakarta: EGC; 2006. p. 64.

10. Bian Z, GuoY, Ha B, Zen K, LiuY. Regulation of the inflammatory response: enhancing neutrophil infiltration under chronic inflammatory conditions. J Immunol 2012;188: 844-53.

11. Cavalcante GM, Paula RJSD, Souza LPD, Sousa FB, Mota MRL, Alves APNN. Experimental model of traumatic ulcer in the cheek mucosa of rats. Acta Cirurgica Brasileira 2011;26(3):227-34.

12. Guyton AC, Hall JE. Buku ajar fisiologi kedokteran. $11^{\text {th }}$ ed. Jakarta; EGC; 2007. p. 452-4, 457-8, 464.

13. Taggart JE, Perry DA. Periodontology for the dental hygienist. $3^{\text {rd }}$ ed. St. Louis: Elsevier; 2007. p.125, 131-132, 150.

14. Kumar H, Sharma A, Attri SK, Kaushik S. Rapid onset peripheral neuropathy: a rare complication of metronidazole. J Indian Acad Clin Med 2012;13(4):346-8.

15. Prasad S, Tyagi AK. Traditional medicine: the goldmine for modern drugs. Adv Tech in Biol Med 2015;3(1):1-2.

16. Harwati CHT. Khasiat jahe bagi kesehatan tubuh manusia. J Inovasi Pertanian 2009;8(1):54-61.

17. Shimoda H, Shan SJ, Tanaka J, Seki A, Seo JW, Kasajima N, et al. Anti-inflammatory properties of red ginger (Zingiber officinale var. rubra) extract and suppression of nitric oxide production by its constituents. J Medicinal Food 2010;13(1):156-62.

18. Jolad SD, Lantz RC, Solyom AM, Chen GJ, Bates $R B$, Timmerman $B N$. Fresh organically grown ginger (Zingiber officinale); composition and effects of LPS-induced $\mathrm{PGE}_{2}$ production. Phytochem 2004;65(13):1937-54.

19. Levy AS, Simon O, Shelly J, Gardener M. 6-shogaol reduced chronic inflammatory response in the knees of rats treated with complete freund's adjuvant. BMC Pharmacol 2006;6(12):1-8.

20. Kruger $P$, Saffarzadeh $M$, Weber ANR, Rieber $N$, Radsak M, Bernuth HV, et al. Neutrophils: between host defence, immune modulation and tissue injury. PLOS Pathogens 2015;1-23. Review.

21. Iba T, Hashiguchi N, Nagaoka I, Tabe Y, Murai M. Neutrophil cell death in response to infection and its relation to coagulation. J Intensive 
Care 2013;1(13):1-10.

22. Lindberg TY, Bage T. Inflammatory mediators in the pathogenesis of periodontitis. Cambridge University Press Review 2013; 15(7):1-22.

23. Putra NRE. Analisis perubahan jumlah dan jenis sel PMN penderita sinusitis kronik pada pengobatan gurah. Minor thesis. Semarang: Universitas Diponegoro; 2012. p. 74.

24. Wijaya O, Sartono TR, Djajalaksana S, Maharani A. Peningkatan persentase makrofag dan neutrofil pada sputum penderita penyakit paru obstruktif kronik berhubungan dengan tingginya skor COPD assessment test (CAT). J Respirologi Indonesia 2012;32(4):240-9.

25. Vieyra RC, Rosales C, Querol EU. Neutrophil functions in periodontal homeostasis. J Immunol Res; 2016:1-9

26. Martin KR, Ohayon D, Witko-Sarsat V. Promoting apoptosis of neutrophils and phagocytosis by macrophages: novel strategies in the resolution of inflammation. Swiss Medical Weekly 2015;1-10. Review.

27. Caielli S, Banchereau J, Pascual V. Neutrophils come of age in chronic inflammation. Curr Opin Immunol 2012:24:671-7.

28. Aldelina NL, Sari DS, Amin MN. Efek pemberian ekstrak daun pepaya muda (Carica papaya) terhadap jumlah sel makrofag pada gingiva tikus Wistar yang diinduksi Porphyromonas gingivalis. Artikel Ilmiah Mahasiswa 2013:3-4.

29. Mashhadi NS, Ghiasvand R, Askari G, et al. Anti-oxidative and anti-Inflammatory effects of ginger in health and physical activity: Review of Current Evidence. Int J Prev Med 2013;4(1):5.

30. Miguel MG. Anthocyanins: antioxidant and/ or anti-inflammatory activities. J Appl Pharmaceut Scie 2011;01(06):7.

31. Tatsuno T, Jinno $M$, Arima $Y$, Kawabata T, Hasegawa T, Yahagi $N$, et al. Antiinflammatory and anti-melanogenic proanthocyanidin oligomers from peanut skin. The Pharmaceutical Society of Japan 2012;35(6):909.

32. Rossa C, Kirkwood KL. Molecular Biology of the host-microbe interaction in periodontal diseases. In: Newman, Takei, Klokkevold, Carranza, editors. Carranza's clinical periodontology. $11^{\text {th }}$ ed. St. Louis: Elsevier; 2012. p. 288.

33. Graves D. Cytokines that promote periodontal tissue destruction. J Periodontol 2008;79(8):1585-9.

34. Carranza FA, Camargo PM, Takei HH. Bone loss and patterns of bone destruction. In: Newman M, Takei HH, Klokkevold P, Carranza FA, eds. Carranza's clinical periodontology. $11^{\text {th }}$ ed. St. Louis: Elsevier; 2012. p. 144. 